\title{
The Effect of Botanical Insecticide Mixed Formulation from Piper aduncum Fruit and Tephrosia vogelli Leaf Against the Diversity of Soil Arthropods in Cabbage Plantation (Brassica oleracea L)
}

\author{
Eka Candra Lina ${ }^{\mathrm{a}, 1}$, Nia Perahas Tiwi ${ }^{\mathrm{a}, 2}$, Martinius ${ }^{\mathrm{a}, 3}$, My Syahrawati $^{\mathrm{a}, 4}$, Bibin Bintang Andriana ${ }^{\mathrm{b}}$ \\ ${ }^{a}$ Department of Plant Protection, Andalas University, Limau Manis, Padang, 25163, Indonesia \\ E-mail: ' ${ }^{2}$ ka_candra@faperta.unand.ac.id; ${ }^{2}$ nia.perahastiwi@gmail.com; ${ }^{3}$ martinius59@yahoo.co.id; ${ }^{4}$ mysyahra@yahoo.com \\ ${ }^{b}$ Department of Biomedical Chemistry, Kwansei Gakuin University, 2-1 Gakuen, Sanda-shi, Hyogo-Ken 669-1337, Japan \\ E-mail: cyd56987@kwansei.ac.jp
}

\begin{abstract}
An arthropod is one of the critical animal groups in the agriculture ecosystem. The purpose of this research is to determine the effect of botanical insecticide mixed with formulation from Piper aduncum fruit and Tephrosia vogelii leaf as well as their application intensity against the diversity of soil arthropods. The research was conducted in cabbage plantation regularly applied with pesticide using Randomized Block Design two factorial with 5 treatments and 3 duplications in three regions (Jorong Jambu Kaniki, Batipuh Atas, and Tanah Datar) from March to July 2017. The treatments included control, WP (wettable powder) botanical insecticide formulation, EC (Emulsifiable concentrate) botanical insecticides formulation, BT (Bacillus thuringiensis) formulation, and synthetic insecticide (chlorfenapyr). Soil arthropod samples were taken by pitfall trap at 75 points representing all treatments. The type of formulations and intensity of application affect the number of soil arthropods individuals. There is an interaction between formulations and intensity of application, enhancement on formulations application of WP, and EC tend to increase the number of soil arthropods individual. Otherwise, the use of synthetic insecticide significantly decreases the number of soil arthropod individuals. The application intensity did not affect the type of soil arthropods. Further identification of soil arthropod samples from the experimental field showed the diversity of soil arthropods is categorized as moderate $(2,23-2,97)$, evenness is categorized medium to high $(0,25-0,65)$, index similarity formulations are categorized high $(0,923-1,000)$, and index similarity intensity application in categorizing medium to high $(0,667-1,000)$. Soil arthropods ware found in cabbage plantations consist of 3 classes: Arachnida (1 Order; 1 Family), Insecta (1 Order; 4 Family), Entoghnata (1 Order; 2 Family). Order Collembola, Family Onychiuridae dominated soil arthropods.
\end{abstract}

Keywords— diversity; soil arthropods; cabbage (Brassica oleraceae L.); botanical insecticides; synthetic insecticides.

\section{INTRODUCTION}

Cabbage (Brassica oleraceae $L$ ) is one of the horticultural commodities with high economic value and still requires serious handling through increasing the yield and quality of cabbage [1]. Cabbage productivity in West Sumatra fluctuated from 2011-2015 in a row namely 31.40; 31,59; $29.49 ; 29.78$ and 31.36 tons/ha [2]. The productivity is relatively low than cabbage's productivity potency in West Sumatra that reaches 40 tons/ha [3]. The low productivity of cabbage was caused by a disruption of Plant Disturbing Organisms (OPT) such as cabbage head caterpillar (Crocidolomia pavonana), leaf caterpillar (Plutella xylostella), soil caterpillar (Agrotis ipsilon), and armyworm (Spodoptera litura) [1]. The yield loss caused by $C$. pavonana and $P$. xylostella reached $100 \%$ without proper control taken immediately [4]. Cabbage pest control is generally carried out by farmers using synthetic insecticides. The excessive and continuous use of synthetic insecticides harms the environment, including resistance, resurgence, the emergence of secondary pests (replacement) and residual buildup in plants [5] and affects soil organisms [6], so that decomposition of organic materials running slow and reduce the amount number of nutrients in the soil. The direct effect of insecticides was in target pests and natural enemies. The rest of the insecticide falls to the ground and accumulate in the soil that affects life and reduces the diversity of soil arthropods [7]. Soil arthropods are soil organisms that play a role in reforming or decomposing soil organic material so that the process of reformation in the soil runs fast [8].

The organisms that are often found in the soil from arthropod groups are Insecta, Arachnida, and Myriapoda. The most common group is Collembola, while the most common Arachnida group is Araneae [9], [10]. Soil 
arthropods life is influenced by environmental factors [11] such as micro factors that affect soil insects' lives, which are seen from the thickness of litter, organic matter content, $\mathrm{pH}$, fertility, soil type, soil density, and soil moisture. Meanwhile, macro factors are from the geology, climate, altitude of places, and plants' types. The loss of arthropods is very influential on the balance of the ecosystem [12]. Thus, insects, especially as decomposers, are unable to recycle organic material; consequently, the benefits become lost and impact their own vegetation and vice versa. Environmentally-friendly farming systems such as organic farming and botanical insecticides can support the survival of soil arthropods. The administration of plant-based pesticides from Ramayana leaves (Cassia spectabilis) and tobacco (Nicotiana tabacum) did not negatively affect the population of soil arthropods [13].

An alternative control technique by utilizing botanical insecticides is a single active ingredient or compound derived from plants. Plant-based insecticides function as repellents, pullers, antifertility, and killers [14]. This class of insecticides is safer and more comfortable than chemicalbased insecticides to apply in the field with several advantages, easily decomposed in nature, relatively safe against non-target organisms, including natural enemies, and enable integration with other components of IPM (Integrated Pest Control) [15], [16]. Botanical insecticides result from extraction from plant parts, either leaves, fruit, seeds, or roots in the form of compounds or secondary metabolites, which have toxic properties against certain pests and diseases. The insecticides work through a combination of various ways or singly. Some ways of plant insecticides working to inhibit skin turnover, disrupt insect communication, inhibit reproduction of female insects, reduce appetite, repel insects, block the ability to eat insects, cause insects to refuse to eat, and inhibit the development of pathogenic diseases [17].

One factor caused the low use of botanical insecticides among farmers, such as the lack of ready-made, effective, and safe botanical insecticides available in sufficient quantities [18]. The botanical insecticides in the form of formulations are more effective and efficient in controlling pests. The use of formulations in agriculture is closely related to safety in storage, ease of application, and active ingredient activity [18]. Formulations that are widely used in agriculture are formulations in the form of emulsifiable concentrate (EC) and wettable powder (WP) [19], [18].

The use of botanical insecticides mixed from two or more plant extracts reduces dependence on one type of plant to minimize potential plant sources' loss as botanical insecticides. Plant species with the potential as a source of botanical insecticides include $P$. aduncum and $T$. vogelii fruit. This mixture of two types of ingredients are more effective and efficient in controlling Crocidolomia pavonana. Testing a mixture of plant-based insecticide $P$. aduncum and $T$. vogelii (5: 1) fruit has good activity and synergistic effects whereas with LC50 and LC95 values of $0.014 \%$ and $0.06 \%$ and the use of formulations in agriculture-related closely with aspects of security in storage, ease of application and activity of an active ingredient [18]. The formulation mixture of $P$. aduncum and $T$. vogelii is safe against natural enemies Eriborus argenteopilosus [18].
The effect of the application intensity of plant-based insecticides mixed with formulations of $P$. aduncum and $T$. vogelii fruit for soil arthropods has never been done before. Based on this, we would like to explore the effect of mixed formulations of botanical insecticides $P$. aduncum and $T$. vogelii leaves and the application intensity on the diversity of soil arthropods in planting Gabbage (Brassica oleracea $L) "$. Therefore, the purpose of this study was to determine the effect of the application of botanical insecticides formulations to the diversity of soil arthropods.

\section{MATERIALS AND METHODS}

\section{A. Materials}

The tools used are rotary evaporator, analytical scales, blenders, $0.5 \mathrm{~mm}$ gauze sieves, $100 \mathrm{ml}$ measuring cups, Petri dishes, pipettes $(1 \mathrm{ml}, 5 \mathrm{ml}$, and $10 \mathrm{ml})$, filter paper, extract bottles, bottle formulations, spatulas, Erlenmeyer flasks, glass funnels $(5 \mathrm{~cm}$ and $9 \mathrm{~cm}$ in diameter size), steam gourds, boiling pumpkins, small brushes, tape, meters, Pitfall traps, microscopes, plastic boxes, plastic bags, bamboo trays, knapsack sprayers, collection bottles, ruler, stationery, and Boror 7 th edition identification book.

The ingredients used during the research are $70 \%$ alcohol, and plant extract ingredients are $P$. aduncum and $T$. vogelii leaves and cabbage seeds (SAKATA varieties), Bacillus thuringiensis, ethyl acetate solvents, pure acetone, methanol, tween 80 , kaolin, aquades, tissue, Whatman filter paper No 41, ordinary filter paper, aluminum foil, rubber, labels, newspaper, synthetic insecticides made from chlorophenapir and logbooks.

This study used a Randomized Block Design (RBD) with 2 factors, namely pesticide formulation including untreated control, WP (wettable powder), EC (Emulsifiable concentrate), while BT (Bacillus thuringiensis) and synthetic insecticides made from active ingredients (klorfenapir) were compared. Application intensity was 0 applications, 5 after application, 10 after application. The study area was chosen, which did not have many local people planting cabbage, and pesticide use was low.

\section{B. Methods}

1) Extraction of Piper aduncum and Tephrosia vogelii: The source plants of Piper aduncum extract were purchased from Bungus Teluk Kabung District (Padang) and Tephrosia vogelii that both are from the Agropolitan Area, Pacet District (Cianjur Regency, West Java). P. aduncum fruits and $T$. vogelii leafs were cut into pieces $( \pm 3 \mathrm{~cm})$, then placed on a bamboo tray covered with newsprint and dried with the wind without being exposed to direct sunlight. After drying, the ingredients were ground using a blender. The blended plant-material were sifted using a $0.5 \mathrm{~mm}$ sieve to obtain a fine form of powder. The used method is the immersion/maceration method using ethyl acetate solvents [18], [20]. In the first stage, $50 \mathrm{~g}$ of $P$. aduncum and $T$. vogelii powder were put into an Erlenmeyer flask separately and soaked in $500 \mathrm{ml}$ of ethyl acetate solvent for 24 hours, then extracted liquid was filtered using a glass funnel $(9 \mathrm{~cm}$ in diameter size), which lied on filter paper and stored with $500 \mathrm{ml}$ Erlenmeyer. The first filter was refiltered using a glass funnel (5 $\mathrm{cm}$ in diameter size), which lay on Whatman 
filter paper no. 41 and stored in a steam flask, then evaporated with a rotary evaporator at a temperature of $50^{\circ} \mathrm{C}$ and a pressure of 250 mbar. Ethyl acetate obtained from evaporation was used to re-soak up the extracted plant pulp up for three times soaking. The extract obtained in the pumpkin was left in a pumpkin mouth with gauze for 3 days until the ethyl acetate smell lost. The obtained thick extract was transferred to a storage bottle, covered with aluminum foil, and given plastic. The extract was stored in a refrigerator with a temperature of $3^{\circ} \mathrm{C}$ before testing.

2) Preparation of Mixed Formulations: An extract mixture formulation that showed the most active toxicity test, T. vogelii and P. aduncum (with a ratio of 1: 5) [18], was used as a base for making liquid formulations (EC: emulsifiable concentrate) and flour (WP: wettable powder). The 20 EC mixture extract formulation was made by mixing $20 \%$ extract with $10 \%$ emulsifier that was able to dissolve the extract and $70 \%$ methanol carrier material (based on volume), then shaking until all ingredients were mixed and ready for use. The preparation of $20 \mathrm{WP}$ mixture extract formulation was made by mixing $20 \%$ extract, $10 \%$ emulsifier and $70 \%$ kaolin (based on weight), and sufficient acetone to make it easier to homogenize the ingredients. After being homogeneous, acetone in the mixture was taken back by evaporating via a rotary evaporator at a temperature of $50^{\circ} \mathrm{C}$ and a pressure of 240 mbar. The evaporated mixture was awaited overnight to ensure there are no remaining acetone. The dried mixture was then scraped from the pumpkin, mashed, and sifted using a $0.5 \mathrm{~mm}$ filter. The mixture formulation of $P$. aduncum and $T$. vogelii extract 20 WP were stored in a light-tight container and placed in the refrigerator.

3) Cabbage planting: Preparation of land and making beds for plot sizes of $4.5 \mathrm{~m} \times 7 \mathrm{~m}$ in the distance between 70 $\mathrm{cm} \times 50 \mathrm{~cm}$ plots arranged in a randomized block design (RBD) with 2 factorials, 5 treatments, and 3 replications in each bed. In each bed, cabbage seedlings were planted with a spacing of $1 \mathrm{~m} \times 1 \mathrm{~m}$. Each bed contained 34 cabbage seedlings labelled at each treatment and replication. The used cabbage seeds were sown first, then after 2 weeks old, the seeds were transferred to the field.

4) Sampling: Sampling used was a pitfall trap, which its installation of pitfall traps was made of plastic cups. The soil was excavated for making the holes inputted with 5 plastic cups into each hole then filled with $70 \%$ alcohol as much as a $1 / 4$ glass of plastic and let stand for 24 hours. The caught insects (sample) found in the aqua glass were collected using tweezers and small brushes, putting into a collection bottle that has been given $70 \%$ alcohol. Each bed consists of 5 pitfall traps. Sampling was carried out three times (namely: 0, 5, and 10 times the application). The trap was then left for $1 \times 24$ hours and continued with the identification of samples in the Insect Bioecology Laboratory.

5) Application in the Field: Application activities were conducted when the cabbage was 3 MTS (weeks after planting) or after the appearance of pest attacking symptoms on cabbage plants. Applications were carried out in the morning with the interval of one-week treatment. The concentration level of botanical insecticides tested was determined based on the results of the toxicity test in the laboratory (equivalent to $2 \times$ LC95) [18]. The application of botanical insecticides was done by making a spray $20 \mathrm{EC}$ with a concentration of $7 \mathrm{ml} / 1$ and $20 \mathrm{WP}$ (a concentration of $7 \mathrm{~g} / \mathrm{l})$, BT application of recommended position as much as $1.25 \mathrm{gr} / 1$, and synthetic insecticides made from active chlorphenapir taken as much as $1.2 \mathrm{ml} / \mathrm{l}$. Spray liquid from each treatment was applied with 2 knapsack sprayers, namely for the application of EC, WP, and BT using 1 knapsack sprayer. Meanwhile, for synthetic insecticides, active chlorfenapyr used 1 knapsack sprayer. The need for spray fluid needed was adjusted to how much we need it in the field. For 10 times of the application, the EC, WP, BT, and the insecticide chlorphenapir formulation required around $238 \mathrm{ml}, 238 \mathrm{gr}, 42.5 \mathrm{gr}$, and $36.48 \mathrm{ml}$, respectively.

6) Identification of Insects: Identification was made in order to observe the insects obtained in the field, which was helpful to know the characteristics of the order until the level of morphospecies. Insects obtained in the field were identified using the Borror and Delong's introduction to insect 7 th book [21].

\section{RESULTS AND DISCUSSION}

\section{A. Research Location Description}

Based on the geographical location of the sampling area (Tanah Datar District, Batipuh Nagari District, Batipuh Ateh, Jorong Jambu Kandikie, and Bato Land positioned at $0^{\circ} 22$ '32 "- 100 30' 00" BT and 0 23 '38 "- $0^{\circ} 34^{\circ}$ ' 25" LS with area of $144.26 \mathrm{~km}^{2}$ ) are geographically classified as plain, with a height of 500-850 meter above sea level. Each location's height varies from flat, bumpy to hilly with an elevation of $\pm 200-1000 \mathrm{~m}$ above sea level [22].

The research location was the former planting of sweet potatoes and around the research area farmers generally plant sweet potatoes. It can be recognized from a land condition that the location of a site determines soil arthropod species' presence. For community livelihoods are vegetable farmers, where the types of vegetables that are most widely planted by farmers are tomatoes, eggplants, and cabbage plants themselves. Farmers in the area rarely plant them due to unable to control pest attacks and costly so that some farmers prefer to plant sweet potatoes rather than cabbage plants.

The condition of land greatly affected the diversity of soil arthropods around it. The diversity was able to be identified from the various aspects such as temperature, weather, location height, cropping pattern, cultivated plants, insecticide use to control pests, and diseases and planting areas that were overgrown with weeds. [23] stated that the abundance of diversity of soil arthropods was highly dependent on their habit. Therefore, the population's existence or density is very dependent on the environment (namely the biotic and abiotic environment).

\section{B. Types of Soil Arthropods in Cabbage Plants.}

As the results of the study found soil arthropods as much as 3 classes of Insecta, Arachnida, entognata, 4 orders (namely Collembola, Coleoptera, Orthoptera, and Araneae) spread in 7 families (namely Onychiuridae, Isotomidae, Cicindelidae, Staphylinidae, Elateridae, Grillydae, and 
Lycosidae). The order of Collembola is found more than the other orders. Collembola can live in various habitats, but it is generally known as soil insects because most of its members live on the ground. These insects have not been widely known in Indonesia; only around 375 species, it is estimated that no less than 1500-2000 species exist [8] and according to [10] Collembola is an insect that is abundant in the soil. Collembola, as well as decomposers, can also increase soil respiration, and accelerate nitrogen mineralization [24].

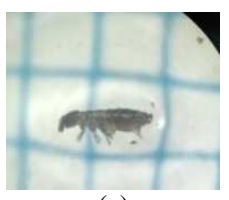

(a)

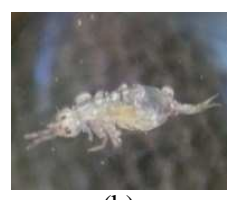

(b)

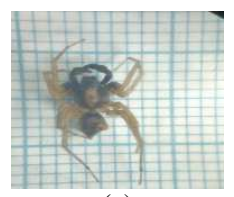

(c)

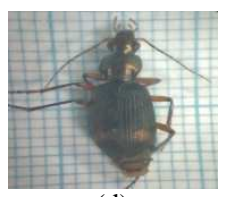

(d)

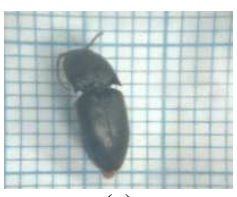

(e)

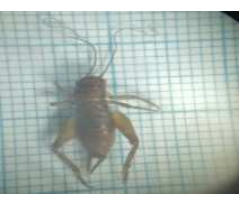

(f)

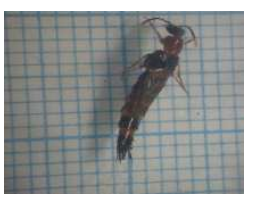

(g)

Fig 1. Family of soil arthropods; A. Onychiuridae, B. Isotomidae, C. Lycosidae, D. Cicindelidae, E. Elateridae, F. Grillydae, G. Staphylinidae.

\section{The Abundance of Soil Arthropod Populations in Cabbage Plants}

The arthropod population was found consisting of 7 species. The dominant soil arthropods were from the family Onychiuridae Colembolla order (Table I). There were as many as 3 classes of Insecta, Arachnida, entognata, 4 orders, namely Collembola, Coleoptera, Orthoptera, and Araneae spread in 7 families Onychiuridae, Isotomidae, Cicindelidae, Staphylinidae, Elateridae, Grillydae, and Lycosidae found as soil arthropods. The order of Collembola was found more than the other orders. Collembola can live in various habitats, but it is generally known as soil insects because most of its members live on the ground. These insects have not been widely known in Indonesia; only around 375 species, it is estimated that no less than 1500-2000 species exist [8], and Collembola is an insect that is abundant in the soil [10]. Collembola and decomposers can also increase soil respiration and accelerate nitrogen mineralization [24].

TABLE I

Abundance Of SoIl Arthropods Populations In CABBAGE Plants

\begin{tabular}{|c|c|c|c|c|}
\hline \multirow{3}{*}{$\begin{array}{l}\text { Name of } \\
\text { Arthropoda }\end{array}$} & \multicolumn{4}{|c|}{ Treatment } \\
\hline & \multicolumn{4}{|c|}{ Control (Number of Application) } \\
\hline & $\mathbf{0}$ & 5 times & 10 times & $\begin{array}{l}\text { total } \\
\text { specimen }\end{array}$ \\
\hline \multirow[t]{2}{*}{ Collembola } & On & On & On & 8.712 \\
\hline & Is & Is & Is & 1.923 \\
\hline \multirow[t]{3}{*}{ Coleoptera } & $\mathrm{Ci}$ & $\mathrm{Ci}$ & - & 4 \\
\hline & St & St & $\mathrm{St}$ & 10 \\
\hline & - & $\mathrm{El}$ & El & 3 \\
\hline Orthoptera & $\mathrm{Gr}$ & $\mathrm{Gr}$ & $\mathrm{Gr}$ & 10 \\
\hline Araneae & Ly & Ly & Ly & 8 \\
\hline \multicolumn{5}{|c|}{ WP (Number of Application) } \\
\hline & $\mathbf{0}$ & 5 times & 10 times & $\begin{array}{c}\text { total } \\
\text { specimen }\end{array}$ \\
\hline \multirow[t]{2}{*}{ Collembola } & On & On & On & 2.697 \\
\hline & Is & Is & Is & 71 \\
\hline \multirow[t]{3}{*}{ Coleoptera } & - & $\mathrm{Ci}$ & $\mathrm{Ci}$ & 3 \\
\hline & St & - & St & 8 \\
\hline & El & - & El & 1 \\
\hline Orthoptera & Gr & $\mathrm{Gr}$ & $\mathrm{Gr}$ & 4 \\
\hline Araneae & Ly & Ly & Ly & 5 \\
\hline \multicolumn{5}{|c|}{ BT (Number of Application) } \\
\hline
\end{tabular}

\begin{tabular}{|c|c|c|c|c|}
\hline & $\mathbf{0}$ & 5 times & 10 times & $\begin{array}{c}\text { total } \\
\text { specimen }\end{array}$ \\
\hline \multirow[t]{2}{*}{ Collembola } & On & On & On & 1.780 \\
\hline & Is & Is & Is & 42 \\
\hline \multirow[t]{3}{*}{ Coleoptera } & $\mathrm{Ci}$ & - & - & 1 \\
\hline & St & St & St & 3 \\
\hline & - & El & El & 2 \\
\hline Orthoptera & $\mathrm{Gr}$ & $\mathrm{Gr}$ & $\mathrm{Gr}$ & 4 \\
\hline Araneae & Ly & Ly & Ly & 4 \\
\hline \multicolumn{5}{|c|}{ EC (Number of Application) } \\
\hline & $\mathbf{0}$ & 5 times & 10 times & $\begin{array}{c}\text { total } \\
\text { specimen }\end{array}$ \\
\hline \multirow[t]{2}{*}{ Collembola } & On & On & On & 2.447 \\
\hline & Is & Is & Is & 45 \\
\hline \multirow[t]{3}{*}{ Coleoptera } & - & $\mathrm{Ci}$ & $\mathrm{Ci}$ & 2 \\
\hline & $\mathrm{St}$ & St & - & 2 \\
\hline & El & El & $\mathrm{El}$ & 2 \\
\hline Orthoptera & $\mathrm{Gr}$ & $\mathrm{Gr}$ & $\mathrm{Gr}$ & 8 \\
\hline Araneae & Ly & Ly & Ly & 3 \\
\hline \multicolumn{5}{|c|}{ Synthetic (Number of Application) } \\
\hline & $\mathbf{0}$ & 5 times & 10 times & $\begin{array}{c}\text { total } \\
\text { specimen }\end{array}$ \\
\hline \multirow[t]{2}{*}{ Collembola } & On & On & On & 468 \\
\hline & Is & Is & Is & 33 \\
\hline \multirow[t]{3}{*}{ Coleoptera } & - & $\mathrm{Ci}$ & - & 1 \\
\hline & $\mathrm{St}$ & $\mathrm{St}$ & - & 2 \\
\hline & - & $\mathrm{El}$ & - & 1 \\
\hline Orthoptera & $\mathrm{Gr}$ & $\mathrm{Gr}$ & $\mathrm{Gr}$ & 4 \\
\hline Araneae & Ly & - & Ly & 2 \\
\hline
\end{tabular}

Note: On (Onychiuridae), Is (Isotomidae), $\mathrm{Ci}$ (Cicaendelidae), $\mathrm{St}$ (Staphylinidae), El (Elateridae), Gr (Gryllidae), Ly (Lycosidae).

\section{Diversity of Soil Arthropods in Cabbage Crops}

The diversity of soil arthropods in cabbage plants ranged from 2.23 to 2.97 among the treatments with a moderate category (Table II). In the study results, we found the soil arthropods as much as 3 classes of Insecta, Arachnida, entognata, 4 orders, namely Collembola, Coleoptera, Orthoptera, and Araneae spread in 7 families namely Onychiuridae, Isotomidae, Cicindelidae, Staphylinidae, Elateridae, Grillydae, and Lycosidae. The order of Collembola is found more than the other orders. Collembola can live in a variety of habitats but is generally known as soil insects because most of its members live on the ground. 
These insects have not been widely known in Indonesia; only around 375 species, it is estimated that no less than 1500-2000 species exist [8] and according to [10]. Collembola is an insect that is abundant in the soil. Collembola and decomposers can also increase soil respiration and accelerate nitrogen mineralization [24].

TABLE II

DIVERSITY INDEX (H ') OF SOIL ARTHROPODS IN CABBAGE PLANTS

\begin{tabular}{|c|c|c|c|c|}
\hline \multirow{2}{*}{ Treatment } & \multicolumn{3}{|c|}{$\begin{array}{c}\text { Diversity of soil arthropods } \\
\text { (Number of application) }\end{array}$} & \multirow{2}{*}{ Average } \\
\cline { 2 - 4 } & 0 & 5 times & 10 times & \\
\hline Control & 2.34 & 2.37 & 2.40 & 2.37 \\
\hline WP & 2.65 & 2.28 & 2.38 & 2.43 \\
\hline BT & 2.70 & 2.23 & 2.42 & 2.46 \\
\hline EC & 2.46 & 2.40 & 2.45 & 2.43 \\
\hline IC & 2.97 & 2.38 & 2.36 & 2.57 \\
\hline
\end{tabular}

Description: WP (wettable powder), BT (Bacillus thuringiensis), EC (Emulsifiable concentrate), and IC (Insecticide Chlorphenapir).

\section{E. Evenness of Soil Arthropods in Cabbage Crops}

Evenness of soil arthropods in cabbage plants ranged from 0.25 to 0.65 between treatments with medium-high categories (Table III).

TABLE III

EvenNess IndeX (E) OF SOIL ARTHROPOds In CABBAGE Plants

\begin{tabular}{|c|c|c|c|c|}
\hline \multirow{2}{*}{ Treatment } & \multicolumn{3}{|c|}{$\begin{array}{c}\text { Evenness of Soil Arthropods } \\
\text { (Number of application) }\end{array}$} & \multirow{2}{*}{ Average } \\
\cline { 2 - 4 } & $\mathbf{0}$ & 5 times & 10 Times & \\
\hline Control & 0.34 & 0.30 & 0.25 & 0.29 \\
\hline WP & 0.41 & 0.63 & 0.33 & 0.45 \\
\hline BT & 0.45 & 0.59 & 0.44 & 0.49 \\
\hline EC & 0.30 & 0.51 & 0.34 & 0.38 \\
\hline IC & 0.45 & 0.60 & 0.65 & 0.56 \\
\hline
\end{tabular}

Description: WP (wettable powder), BT (Bacillus thuringiensis), EC (Emulsifiable concentrate), and IC (Insecticide Chlorphenapir).

The low evenness index value indicates that there is a dominant species, whereas if high evenness means, there is no dominant species. The evenness index of soil arthropods in cabbage plantations ranged from 0.25 to 0.65 classified as medium-high, meaning that individual families' distribution is relatively even and there is no dominant family. [26] stated, the species evenness index was very sensitive to the abundance of species in the sample. Evenness values tends to be high if the number of species populations dominates cropping, whereas evenness tends to be low if a species has a small amount in cultivation.

This is presumably because the species found in cabbage plants can live well together. Factors that affect the evenness of each species are environmental factors, namely climate, and light intensity.

\section{F. Similarity Index / Similarity (IS) of Soil Arthropods in Cabbage Crops}

TABLE IV

SIMILARITY INDEX (IS) OF SOIL ARTHROPODS TO FORMULATION IN CABBAgE Plantations

\begin{tabular}{|c|c|c|c|}
\hline \multirow{2}{*}{ Treatment } & \multicolumn{3}{|c|}{$\begin{array}{c}\text { Formula } \\
\text { (Number of application) }\end{array}$} \\
\cline { 2 - 4 } & $\mathbf{0}$ & $\mathbf{5}$ times & $\mathbf{1 0}$ times \\
\hline Control & 1.000 & 0,923 & 0,923 \\
\hline
\end{tabular}

\begin{tabular}{|c|c|c|c|}
\hline WP & 1.000 & 0,923 & 0,923 \\
\hline BT & 0,923 & 1.000 & 1.000 \\
\hline EC & 1.000 & 0,923 & 0,923 \\
\hline IC & 0,923 & 1.000 & 1.000 \\
\hline
\end{tabular}

Description: WP (wettable powder), BT (Bacillus thuringiensis), EC (Emulsifiable concentrate), and IC (Insecticide Chlorphenapir).

TABLE V

SIMILARITIES IN SOIL ARTHROPODS (IS) TO APPLICATION INTENSITY IN CABBage Plantations

\begin{tabular}{|c|c|c|c|}
\hline \multirow{2}{*}{ Treatment } & \multicolumn{3}{|c|}{$\begin{array}{c}\text { Application Intensities } \\
\text { (Number of application) }\end{array}$} \\
\cline { 2 - 4 } & $\mathbf{0}$ & $\mathbf{5}$ times & 10 times \\
\hline Control & 1.000 & 1.000 & 1.000 \\
\hline WP & 1.000 & 0.857 & 0.933 \\
\hline BT & 0.923 & 0.667 & 0.857 \\
\hline EC & 1.000 & 0857 & 0.857 \\
\hline IC & 0.923 & 0.933 & 0.727 \\
\hline
\end{tabular}

Description: WP (wettable powder), BT (Bacillus thuringiensis), EC (Emulsifiable concentrate), and IC (Insecticides Chlorphenapir).

The index value of soil arthropods' similarity in cabbage plants at each sampling (Table IV). The similarity index of soil arthropods on the formulation in cabbage plantations ranged from $0.923-1,000$ can be seen in Table IV that the administration of various formulations for very similarities. The index similarity of soil arthropods in cabbage plants on application intensity ranged from 0.667 to 0.923 that can be seen in Table IV, the intensity of application for similarity is classified as medium-high. This shows that the types of soil arthropods found in each of these treatments were relatively the same. According to [27] the diversity of living things played an important role in maintaining the balance of the ecosystem. The more diverse of living things that exist in an ecosystem, it is making the ecosystem more stable.

\section{G. Effect of formulation and application intensity on the number of individual soil arthropods in cabbage plants.}

There was an interaction between formulation and the intensity of application affecting the number of individual soil arthropods in cabbage plants $(\mathrm{F}=2.58 ; \mathrm{P}=0.0284)$. Giving the chlorphenapir formulation at the intensity of the application reduced the number of individual arthropods in cabbage plants. However, the more frequently applied on cabbage cropping land tends to increase the number of individuals, especially seen in WP and EC. the intensity of BT application and chlorphenapir did not affect the number of individual soil arthropods in cabbage plantations.

Application of WP and EC formulations did not cause some differences in the number of individual arthropods at the application intensity. The differences in the application of WP, EC, and BT formulations did not cause the differences in the number of arthropod individuals at the application intensity of 0 applications and at 5 times and 10 times after application for WP and BT formulations caused the differences in the number of arthropod individuals. EC and BT formulations did not cause the differences in the number of individuals. The provision of WP and EC formulations further increases soil arthropods compared to BT formulations.

The application of BT formulations to chlorphenapir did not cause the differences in the number of soil arthropod 
individuals at application intensity i.e. 0 applications and at 5 times and 10 times after application caused the differences with the number of soil arthropod individuals. The chlorphenapir formulation application between the three applications intensities did not cause the differences in the number of individual arthropod individuals. When compared with the application of the WP formulation causing the differences in the number of individuals against soil arthropods in cabbage plants. The application of EC formulation to chlorfenapyr did not cause a difference in the number of individual arthropods at the application intensity of 0 applications, while 5 after and 10 after application caused the differences in the number of individual arthropod individuals. Giving formulations between BT and chlorfenapyr showed that BT administration was safer than chlorfenapyr.

As the study results, the mixture of Piper aduncum and Tephrosia vogelii with extract formulations (5: 1), the application of various formulations of insecticides and application intensity significantly affected the number of soil arthropod individuals. This shows that the more frequently applied on cabbage crop land, there is a tendency to increase the number of individuals in cabbage plantations seen in the WP and EC formulations. [28] stated that the synergistic nature of the mixture of $P$. aduncum and $T$. vogelii extracts was the active material of dilapiol compounds contained in $P$. Aduncum fruit. Dilapiol compounds can inhibit the work of the cytochrome P450 polysubstrat monoxygenase (PSMO) enzyme, which has a function to reduce the toxicity of metabolites in the body, thus the active ingredients of $T$. vogelli leaves cause active compounds, namely rotenone. Rotenone works directly towards cells by inhibiting electron transfer to inhibit cell respiration and decrease ATP (energy) production. Consequently, cell activity is inhibited, causing insects become paralyzed and die [29]. This is presumed that the proposition of more $P$. aduncum concentrations causes a greater inhibition of enzyme activity. The active compounds of $T$. vogelii can avoid decomposition by these enzymes continuing to attack the target parts [30]. The use of excessive synthetic insecticides reduces the amount of litter or vegetation in a field that can affect the diversity of the number of soil arthropods in one of the cabbage plantations [31] (Odum, 1993).

TABLE VI

EFFECT OF FORMULATION AND INTENSITY OF APPLICATION ON THE NuMBER OF INDIVIDUAL SOIL ARTHROPODS IN CABBAGE PLANTS

\begin{tabular}{|c|c|c|c|l|}
\hline \multirow{2}{*}{ Formula } & \multicolumn{3}{|c|}{$\begin{array}{c}\text { Application Intensities } \\
\text { (Number of application) }\end{array}$} & \multirow{2}{*}{ Average } \\
\cline { 2 - 4 } & 0 & 5 times & 10 times & \\
\hline Control & 2213.0 c & 2596.7 b & 3128.0 a & 2649.9 \\
\hline WP & 688.7 fgh & 1010.7 def & 1295.7 d & 9983.7 \\
\hline BT & 574.0 ghi & 557.7 ghi & 782 efhg & 637.9 \\
\hline EC & $499.3 \mathbf{~ h i j ~}$ & 877.0 efg & 1125.0 de & 8337.7 \\
\hline IC & 225.0 ijk & 175.3 jk & $107.3 \mathbf{~ k}$ & 169.2 \\
\hline Average & 840.0 & 10434.8 & 1287.6 & $(+)$ \\
\hline
\end{tabular}

Description: WP (wettable powder), BT (Bacillus thuringiensis), EC (Emulsifiable concentrate), and IK (Insecticides Chorphenapir). The numbers on the same lane are followed by lowercase letters, which are not the same significantly different according to the LSD test at the $50 \%$ real level
H. Effect of formulation and the intensity of application on types of soil arthropods in cabbage plants.

The study results showed no interaction between the formulation and the intensity of application to the diversity of soil arthropods in cabbage plantations $(\mathrm{F}=1.28 ; \mathrm{P}=$ 0.290). Giving various types of different formulations, significantly affected the diversity of soil arthropods ( $\mathrm{F}=$ 3.62; $\mathrm{P}=0.016$ ) and different application intensities, did not significantly affect the diversity of soil arthropods $(F=0.79$; $\mathrm{P}=0.464$ ). The application of various types of insecticidal formulations tends to reduce the type of soil arthropods in cabbage plants. The application of the chlorfenapyr formulation further reduces soil arthropods compared to the WP and EC formulations. EC formulations are better able to improve soil arthropods than other formulations.

The effect of the mixture extract formulation of Piper aduncum and Throsia vogelii (5: 1) can reduce the diversity of soil arthropods in cabbage plants. Application intensity did not affect the diversity of soil arthropods in cabbage plants. We assumed that the application of insecticides were washed by rainwater, therefore there was not accumulated properly and the formulations falling into the soil that did not affect the arthropod species. EC formulations' application was easier, without residue in plants, but has phytotoxic risks, including during storage and separation can reduce the effectiveness of formulations [19]. Meanwhile, WP formulations were easier to store, have a low risk of phytotoxicity, and deficiencies require constant stirring during application, leaving residues on plants.

TABLE VII

EFFECT OF FORMULATION AND INTENSITY OF APPLICATION ON SOIL ARTHROPOD TYPES IN CABBAGE PLANTS

\begin{tabular}{|c|c|c|c|l|}
\hline \multirow{2}{*}{ Formula } & \multicolumn{3}{|c|}{$\begin{array}{c}\text { Application Intensities } \\
\text { (Number of Application) }\end{array}$} & \multirow{2}{*}{ Average } \\
& $\mathbf{0}$ & $\mathbf{5}$ times & $\mathbf{1 0}$ times & \\
\hline Control & 4.3333 & 6.0000 & 6.0000 & $5.4444 \quad$ a \\
\hline WP & 4.0000 & 3.0000 & 5.0000 & $\begin{array}{l}4.0000 \\
\text { bc }\end{array}$ \\
\hline BT & 4.3333 & 3.3333 & 4.3333 & $\begin{array}{l}4.0000 \\
\text { bc }\end{array}$ \\
\hline EC & 5.3333 & 4.6667 & 4.6667 & $4.8889 \mathrm{ab}$ \\
\hline IC & 4.3333 & 3.3333 & 3.0000 & $3.5556 \quad$ c \\
\hline Average & 44.666 & 40.666 & 46.000 & $(-)$ \\
\hline
\end{tabular}

Description: WP (wettable powder), BT (Bacillus thuringiensis), EC (Emulsifiable concentrate), and IK (Insecticides Chlorphenapir). The numbers on the same lane are followed by lowercase letters which are not the same significantly different according to the LSD test at the $50 \%$ real level

\section{CONCLUSION}

The finding was the available of soil arthropods in cabbage plants, which consisted of 3 classes: Arachnida (1 order and 1 family), Insecta (1 order and 4 families), Entognata ( 1 order and 2 families). The dominant type of soil arthropod is the family Onychiuridae (Collembola). The effect of mixed formulations treatment made from Piper aduncum and Tephrosia vogeli (5: 1) to the diversity of soil arthropods are classified as moderate (2.23 - 2.97), evenness of soil anthropods is classified as medium-high (0.23-0.65). The similarity index of soil arthropods on cabbage 
plantations' formulation ranged from 0.923 to 1,000 and classified as very high. The intensity of application ranged from 0.667 to 0.923 are classified as medium-high. There are interaction formulations and application intensity. The more frequent application of WP and EC formulations tends to increase the number of individual arthropods. There is no interaction between the formulation and the intensity of application to the type of soil arthropods. WP formulations reduce soil arthropod types, but it is none for EC formulations. Meanwhile, the intensity of application affected the type of soil arthropods. The provision of excessive synthetic insecticides impacts the environment and reduces soil arthropods in a field.

\section{ACKNOWLEDGMENT}

Special thanks to the Andalas University for the academic and technical support to complete this research.

\section{REFERENCES}

[1] Permadi, A.H. dan S, Sastrosiwojo. (1993). Kubis. Badan Penelitian dan Pengamatan Pertanian Balai Penelitian Penelitian Hortikultura Lembang.

[2] Badan Pusat Statistik (BPS). (2016). Produksi Sayuran di Indonesia. http://www.pertanian.go.id/ap_pages/mod/datahorti $[22$ Oktober 2017].

[3] Dinas Pertanian Tanaman Pangan dan Hortikultura (DPTPH) Sumatera Barat. (2010). Perkembangan Tanaman Hortikultura Tahun 2009 di Sumatera Barat. Padang.

[4] Rueda, A, AM Shelton. (2006). Diamondback Moth (DBM).www.nysaes.cornell.edu. htm. (Diakses tanggal 10 April 2012).

[5] Pimentel, D. (1982). Perspectiver of Integrated Pest Management. Crop Protection, 1(1), 5-26.

[6] Soetikno, S dan Sastroutomo. (1992). Pestisida Dasar- dasar dan Dampak Penggunaaanya. Gramedia. Jakarta.

[7] Khan, M Z. (2003). Effect of Pesticides On Biodiversity:comparison of Malathion with Biosal on Protein Contents in Calotes versicolor. J.nat.hist.wildl, 2(1),25-28.

[8] Suhardjono, Y.R. (1998). Serangga Serasah :Keanekaragaman Takson dan Peranannya Di Kebun Raya Bogor. Biota. 3(1), 16-24.

[9] Wallwork, J. A., (1970). Ecology of Soil Animal.Academic Press. London.

[10] Borror, D.J., C. A. Triplehom, and N. F.Johnson. (2005). Pengenalan Pembelajaran Serangga . Edisi keenam. Gajah Mada Universitiy Press. Yogyakarta.

[11] Purwowidodo. (2003). Panduan Praktikum Ilmu Tanah Hutan: Mengenal Tanah. Fakultas Kehutanan IPB, Bogor.

[12] DeBano, C.F.D.G., Neay dan P.F. Folliot. (1998). Fire's Effect On Ecosystem. New York. John Wiley and Sons. Inc.
[13] Wiryadiputra, S. (2006). Keefektifan Pestisida Nabati Ramayana (Cassia spectabilis) dan Tembakau (Nicotiana tabacum) Terhadap Hama Utama Tanaman Kopi dan Pengaruhnya Terhadap Arthropoda Lainnya. Pelita Perkebunan, 22 (1), 25-39.

[14] Syakir, M. (2011). Status Penelitian Pestisida Nabati Pusat Penelitian dan Pengembangan Tanaman Perkebunan [Semnas Pesnab IV]. Bogor.

[15] Prakash, A., Rao, J. (1997). Botanical Pesticides In Agriculture. Boca Raton: CRC Press.

[16] Dadang., Prijono, D. (2008). Insektisida Nabati : Prinsip, Pemanfaatan, dan Pengembangan . Bogor: Departemen Proteksi Tanaman, Institut Pertanian Bogor.

[17] Sudarmo, S. (2005). Pestisida Nabati. Jakarta: Kanisius.

[18] Lina, E.C. (2014). Pengembangan Formulasi Insektisida Nabati Berbahan Ekstrak Brucea javanica, Piper aduncum, dan Tephrosia vogelii Untuk Pengendalian Hama Kubis Crocidolomia pavonan.[Desertasi] Bogor. Sekolah Pascasarjana Institut Pertanian Bogor.

[19] Mollet, H and Grubenmenn. (2001). Formulation Technology: Emulsion, Suspensions, Solid Forms. Wiley-VCH Verlag.

[20] Abizar M dan Prijono J. D. Hooker. (2010). Aktivitas insektisida ekstrak daun biji Tephrosia vogelii (Leguminosae) dan ekstrak buah Piper cubeba L. (Piperaceae) terhadap larva Crocidolomia pavonana (F.) (Lepidoptera:Crambidae). JHPT tropika, 10,1-12.

[21] Triplehorn C.A dan N.F Johnson. (2005). Borror and Delong's introduction to the study of insect 7th Ed. Belmont: Thomson Brooks/cole.

[22] Badan Pusat Statistik (BPS). (2017). Kabupaten Tanah Datar dalam Angka. Tanah Datar.

[23] Suin,N.M.(2012). Ekologi Hewan Tanah: Jakarta.Bumi Aksara.

[24] Kaneda S, Kaneko N. (2004). Growth of the Collembolan Folsomia candida Willem in soil supplemented with glucose. Pedobiologia, 48,165-170.

[25] Krebs, C. J. (2000). Ecological Methodology. Second Edition. New York: Animprint of Addison Wesley Longman, Inc.

[26] Magurran, A.S. (1988). Ecological Diversity and Its Meeasurement. Chapman and Hall. London.

[27] Waris. (2009). Ekosistem dan Pelestarian Sumber Daya Hayati. http://189.89.2012.211/explorer/view.php. [ 15 juli 2016].

[28] Bernard C.B., H.G Krishnamurty., D Chauret., T Durst., B.J.R Philogene. 1995. Insecticidal defenses of Piperaceae from the Neotropics. Journal Chem Ecol, 2(1),801-814.

[29] Hollingworth, R.M. (2001). Inhibitors and uncouplers of mitochondrial oxidative phosphorylation. Di dalam: Krieger R, Doull J, Ecobichon D, Gammon D, Hodgson et al., editor. Handbook of Pesticide Toxicology. San Diego (US): Academic Press.11691227.

[30] Nailufar, N. (2011). Aktivitas Insektisida Ekstrak Daun Tephrosia vogelii (Leguminosae) dan Buah Piper aduncum (Piperaceae) Terhadap Larva Crocidolomia pavonana [Skripsi]. Bogor. Institut Pertanian Bogor.

[31] Odum, E.P. (1971). Fundamentals of Ecology. Third Edition. Saunders Company. Philadelphia and London. ofinseticide Mixtures For The Control of The tobacco Budworm (Lepidoptera:Noctuidae).J Econ Entomo, 18(1), 989-994. 